Fidan Begolli, Ph.D. student

University of Rijeka, Faculty of Economics, Rijeka, Croatia, fidanbegolli@hotmail.com

\title{
EUROPEAN UNION INTEGRATION PROCESS AND ITS CHALLENGES FOR KOSOVO
}

Received: October 15, 2018

Accepted: December 20, 2018

Review

\begin{abstract}
European integration is process that has rules which must be followed from all aspirant countries, as well as with a great dedication to the process. Kosovo and its integration into the European Union, has in front very difficult road to be passed. Main objectives of Kosovo is being member of European Union. To achieve that, threshold mentioned in articles 49 and 6 of European Union Treaty should be passed. Being part of European Union, Kosovo must respect all principles mentioned in article 6.

Function of rule of law system is very important for economic development of Kosovo and its integration in European Union. Even there exists commitment from Governmental institutions of Kosovo for empowering rule of law, problems and challenges that Kosovo faces in this field are complex and much more in number, and much more must be invested in all types of resources in order to achieve requested corrections. Legal system of Kosovo still can be described as one of the most complex systems and that represents obstructions for security and legal clearance. As multidimensional process, complex and dynamic, integration process is based in the fact that even European Union together with its institutional structures are in ongoing reforms. Reforms process is requested for the reason of continuously integrations processes of new countries in European Union structures. European Union today faces big challenges, in one side there is challenge of democratic, politic and economic control of candidate countries and in other side internal reforms for its own structures. Today, very important issue of Kosovo is European Integration process. Based in main objectives and achievements that Kosovo has made in this direction, large institutional commitment exists for this process. Especially there are many economic challenges for Kosovo including implementation of CEFTA Agreement, as pre-entrance instrument in European Union.
\end{abstract}

Keywords: CEFTA, Kosovo, European Union, European Commission, Stabilization and Association Agreement etc. 


\section{INTRODUCTION}

With its 28 member states, European Union is powerful force (for good intent) in the world. European Union is the biggest common market in the world, which makes $1 / 4$ of the total economic global production and $1 / 5$ of the world's trade. With more than 508 million residents, is the $3^{\text {rd }}$ biggest market in the world as per residents, after China and India. 24 official languages and more than 60 indigene, regional and minority languages from the residents in the whole European Union. By being together as states in the continent, unseen historically to spread common values and common work benefits, especially in political and economic issues.

European Union works under the integration principle, known as vertical as well as horizontal. Vertical integration or Union creation, happens when member states agree to separate or to transfer their national competences in European Union level, by agreeing that policies can be implemented better in that level. For example, 19 of 28 member states, are using common European currency Euro, and 25 states (including 3 states that aren't EU member), have removed borders among them according to the Schengen Agreement. Horizontal integration or Union expansion, has to do with Union expansion to include other European countries as European Union members. This offer is opened, especially for Western Balkan countries. Until European Union deepens and expands, it continues to change and to get developed, by getting adapted for its member state's needs.

Moreover, European Integration is long process. Those countries that has aim to be part of European Union, must fulfill required standards, by sharing same democratic values, market based economic principles same as existing member states. Respective country must have functional market economy to challenge with competitors in the European Union level and the ability to implement tasks (not only benefit's) of being European Union member. Approval and approximation of national legislation and processes with levels and standards of European Union has nothing to do with translation and approval of a law, but more with a long time transformation process, during which candidate countries can learn how existing member states have acted, because by their self, they implement necessary reforms in order to make possible membership into the European Union.

As it is seen from the last European Union expansion processes, many countries of Central and Eastern Europe, like Malta, Cyprus, Bulgaria, and Romania and in recent time Croatia became member of European Union. Integration process is progressive and transformative. More than 66 years after the creation of the European Union, Western Balkan countries, by joining European Union, has become their main political objective. European Union is main partner of Kosovo. Today, European Union is the biggest foreign investor in Kosovo, and its main 
trade partner, except offering half of international aid in Kosovo. As newest democracy in Europe, Kosovo today is advancing in its European Integration process, and continues to play key role in institutional and legal development.

\section{EUROPEAN INTEGRATION PROCESS}

One of the main objectives for Kosovo is being member of European Union. For such membership, threshold should be passed as it is set in article 49 and 6 of the European Union treaty, respectively Kosovo can be European Union country which respects defined principles in article $6^{1}$. According to the article 6 of the European Union Treaty, there are basic principles on which European Union is created and that must be respected from each new member, which includes among all the principle of rule of law. Rule of law principle, restated in so-called "Copenhagen Criteria" of the year 1993, must be fulfilled from each state candidate, as condition for their membership in European Union. In fact, this principle, is one of the most fundamental principles of the European Public Right, and includes a number of concepts and other different conclusions. However, content of this principle can be taken out from a comprehensive analyze of the European Union member state constitutions and jurisprudence of the European Court of Justice.

Figure 1. European Integration Process

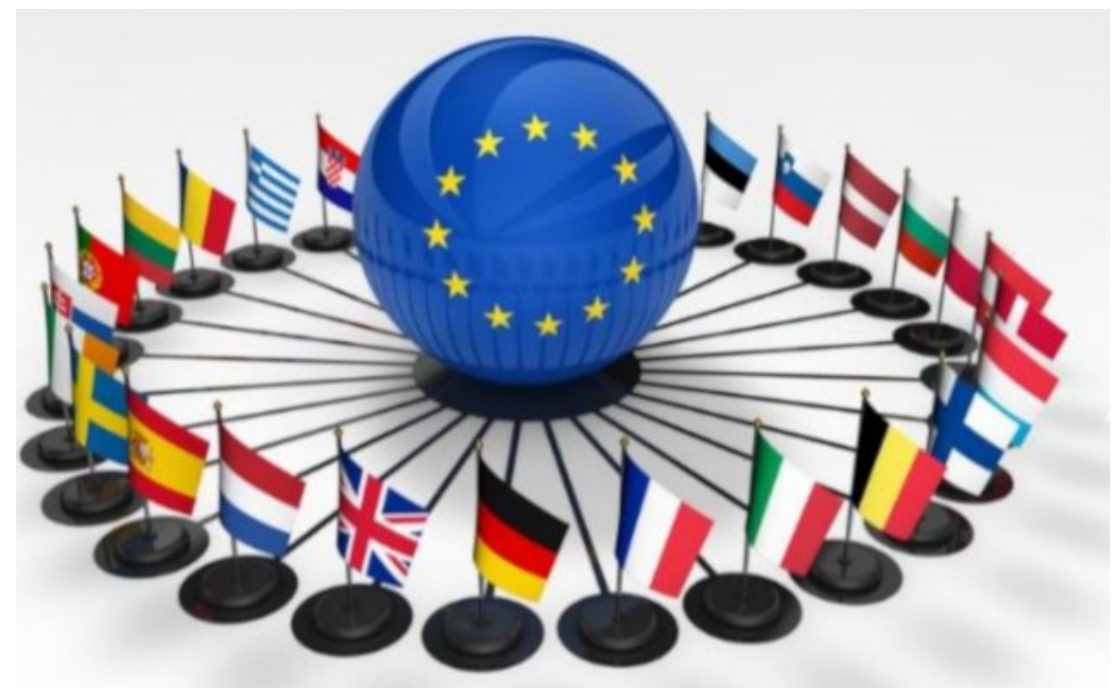

Source: Etias (European Automated Information System of Viagem)

\footnotetext{
${ }^{1}$ Karl Doehring: Allgemeine Staatslehre, Heidelberg: 2000, pp. 170.
} 
Function of the rule of law system, is among the most important issues for economic development in Kosovo and its integration process in European Union. Even it exists as verbal commitment from Kosovo authorities for the enforcement of rule of law, problems and challenges which Kosovo faces in this field are very complex and they are more in quantity, and must include investments in many resources in order to achieve necessary corrections. Juridical system of Kosovo still can be described as one of the most complex systems which represents obstructions for security and juridical clearance. Processes for creation of primary and secondary legislation, requires more focus on the concept "politics before the law" and must be opened and by having more toward transparency and democratic participation, before any legislation is being approved. Kosovo needs security and juridical clearance, especially in sensitive fields known as property right, since only one juridical security, clearance and stability will create necessary framework for investments and entrepreneurship, which it is meant that Kosovo will generate necessary economic development and social stability. Well-structured juridical system can serve for its goals, only if it is administrated from regular and functional juridical system, which despite many efforts, still remain one the weakest pillars of Kosovo's public institutions. Investments in human resources through better juridical education in both levels, academic and professional, presents the most important elements. Courts, especially Basic Courts, has the need for more care in form of better financing, as well as investments in infrastructure and human resources, because in opposite, capacities cannot be faced in successful way with bigger number of cases collected from the past years. Independent functionality of the Juridical Council of Kosovo is primary important issue for having positive results in juridical sector, but main challenge isn't to secure just formal independence of juridical institutions, but substantial independence of judiciary from executive interventions, especially in budget field and administration staff. Despite difficult problems and challenges that are in great number, state of Kosovo and created presence of European Union in the field of rule of law, has the opportunity to undertake necessary reforms and to avoid possible mistakes that were made during Interim Administration of United Nations.

Rule of law known as "Rechtsstaat" or "Etat de Droit", equivalent from German and French Constitutional Right, has general meaning which concludes that there must exist Law Government, not People government. First of all, this can be described as everything must be made as per law, especially every public authority, which takes any action, must be able to justify its actions that are authorized as per law (general principle) $)^{2}$.

Second ascertainment of the rule of law principle is that public authorities must be in line with the rule and principle framework, which limits freedom power of taking actions, with the aim to prevent the misuse of such power. State candidates

${ }^{2}$ Wade, W, Forsyth, C, (2004), Administrative Law, Oxford 
must have stable institutions, which can guarantee democracy, rule of law, human rights and respect and minority protection ${ }^{3}$.

Approximation and advancement of the relations between European Union and Western Balkan countries, including Kosovo, as process today is very important, based in final goal of those countries for being part of European Union. European expansion agenda will secure support for institutional reforms, financial support, economic reforms, market liberalization, also support for democracy and legislation consolidation in accordance with European standards. Some aspects or main mechanisms of cooperation and connection with Kosovo are: conducting mechanism of Stabilization and Association 2002, as instrument which involves Kosovo in European way, Thessaloniki Summit 2003 - reconfirmed European Union commitment toward Western Balkans, by promising European perspective, European partnership is important instrument of European Union in duties implementation and requests that were given from European Union toward Kosovo.

Yearly progress report is one mechanism, through which work and progress of Kosovo institutions can be seen. It is considered that reforms in accordance with European Union standards are one of the most effective measures for speeding and successful passing of transitional process and in the same time advancing the process of European Integration. Those objectives consist with action plan of European partnership, and also with Copenhagen Criteria for European Union integration ${ }^{4}$.

Western Balkans countries (Kosovo, Albania, Macedonia, Montenegro, Serbia and Bosnia and Hercegovina), are continuing to face different challenges, which are shown as obstacle and that do have impact in Brussel's hesitation about secure accesses that countries of this region can in faster way be part of European Union. Unsolved ethnic and among state cases of those countries, as result of post war, have impact in his process, and other challenges known as lack of legal sustainability, corruption, unemployment, organized crime, are causes that force European Union to have hesitant approach toward those countries.

In context with challenges that Kosovo had and continues to have, there are meanings that political achievements made in Kosovo are connected with a wide range of action fields in Kosovo's and International Institutions, both in local and central level. There are some integration challenging fields: building a healthy institutional basement, preparing legal framework and building respective structures, adoption of government efficient capacities in local level, creation of

${ }^{3}$ European Community Commission: Communication of the Commission for European Parliament and Council, (2008), Western Balkans: Correction of European Perspective.

4 Copenhagen Criterias for European Union integration are: 1. Politics Criterial, 2. Economic Criteria, 3. European Standards Criteria - Eu Acquis. 
healthy economic structures and successful management of the privatization process within the existing legal definitions.

Many people are considering this process as unreturnable. Within the wider plan, there is no doubt with the other candidate states, including Republic of Kosovo, that this integration process can be considered stable and unreturnable, despite being difficult to be foreseen in time. Preconditions for membership remains the same: strong state with effective state administration, strengthening of rule of law, improvement of economic growth conditions and expansion of regional cooperation ${ }^{5}$.

However, Kosovo in relationship with EU, have to deal with strong and perspective organization. European Union has achieved high scale of enlargement. After XXI century, European Union enlargement process is made toward Eastern and Southeastern part of Europe, and with final aim to include Western Balkan countries. Process of European Integration, has the aim to get expanded further more in the East of the continent. Integration or main objective of European Union, in continuous way, is the creation of serious economic cooperation order among countries. In later processes, goals are forced in political cooperation objectives, in security and culture field.

Figure 2. Kosovo and European Integration process

Kosovo - Eu Relations:

The History of Unfulfilled Aspirations?
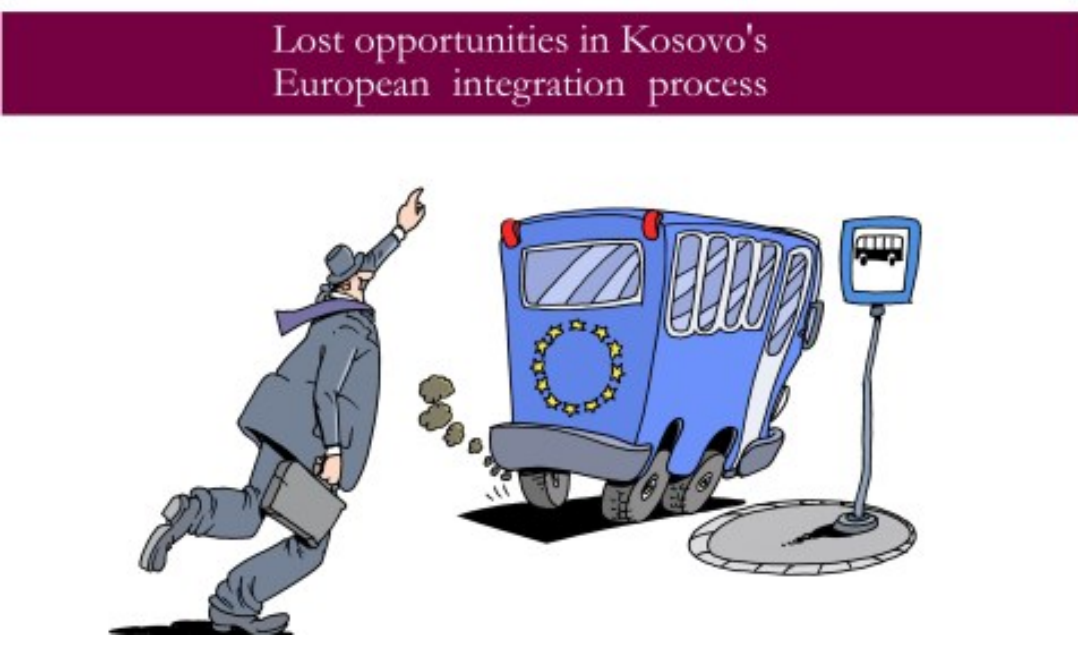

Source: KFOS (Kosovo Foundation for Open Society)

${ }^{5}$ Preci, Z, (2013), Integrimi Europian, Tiranë, 
From an initial organization in the frame of regional cooperation, European Union today is organization with wider dimensions of expansion in continental level and even more. As it is seen today, globalization processes and regional cooperation have helped each other. Globalization as process in great extent has intensified the need for regional cooperation of states all over the world and this cooperation is seen as opportunity to build good relations in business and economic field, and has in focus solving regional development problems, economic cooperation, searching of natural resources, free movement of people and goods, capital, labor force, etc.

Kosovo as new state, which pretends to enter European Union, faces same problems as their neighbors, and in other side, in great extent is facing political problems, especially in relation with Serbia, for known opened issues. But, agreements that are achieved in Brussels and which they regulate normalization of relations between both countries, are primary signal in the direction to create political stability in the region. However, agreements between both countries must be implemented in practice. Agreement implementation still remains concrete challenge, and dialogue continuation remains as perspective of building good neighborhood relations and de jure recognition between both states.

\section{KOSOVO'S ECONOMY}

In global policy, today is undisputable tendency of globalization process that slowly, but surely, is overshadowing dynamic development frames in world, with the aim of marginalization of organizational and management traditional forms in inhabitants life, as those processes got out as serious obstacles in integration process. In this context, is seen that trend of new competencies which flows from discourse values of state sovereignty, that for globalists is identified as "stocks" of special type, there isn't any characteristic exclusion when it is in question process of adding their global interests.

Biggest dilemma that exists today among globalization sociologists, is when those bigger changes are in question, is role and future perspective of state institutions. For developed countries, respective dilemma somehow is materialized through new integrated forms, and for developing countries, there is still stumble and hesitation as per role institutions as a part of competency transfer process in new regional integration forms. For Kosovars, in comparison with others neighbor nations, nature of internal issues, when building process of state institution capacities is in question, all over there are specifics that cannot be seen in any other development process of building state institutions in the world.

In Kosovo, since the case of building state institutions is still actual, mainly, in thick stripes, there are two quality rare specifics that can be identified and that nowhere else can't be find and that is the specific of elementary democratic infrastructure building and goals realization, for building such elementary 
infrastructure with above mentioned institutional mechanism, which for other's has started to have changes and deep modifications in the form and its content for the reason of new globalization processes.

If we address to the permanent goal of Kosovars and that is building identification mechanism which can be used for new national identity, is gained impression that this process is identified not as need of commodity, for as existence of its citizens during the whole past century in new conditions and circumstances' of a process affirmed as globalism, then with no doubt it is required to understand new surrounding development trends. This way of access must be involved also for the historic delay that Kosovars have suffered not with their fault.

Figure 3. Economic growth level of East and Southeastern European countries

\begin{tabular}{|c|c|c|c|}
\hline & 2015 & 2016 & 2020 \\
\hline Albania & $\begin{array}{l}3.0 \\
2.7\end{array}$ & $\begin{array}{l}3.0 \\
3.4\end{array}$ & $\begin{array}{l}3.4 \\
4.2\end{array}$ \\
\hline Bosnia and Herzegovina & 2.0 & 3.0 & 4.0 \\
\hline Bulgaria & 1.7 & 1.9 & 2.5 \\
\hline Croatia & 0.8 & 1.0 & 1.8 \\
\hline Hungary & 3.0 & 2.5 & 2.1 \\
\hline Kosovo & 3.2 & 3.8 & 4.1 \\
\hline FYR Macedonia & 3.2 & 3.2 & 3.8 \\
\hline Montenegro & 3.2 & 4.9 & 3.3 \\
\hline Poland & 3.5 & 3.5 & 3.6 \\
\hline Romania & 3.4 & 3.9 & 3.3 \\
\hline Serbia & 0.5 & 1.5 & 4.0 \\
\hline Turkey & 3.0 & 2.9 & 3.5 \\
\hline
\end{tabular}

Source: IMF (International Monetary Fund)

At the end, it is better for the integrational process that this problem can be solved which includes also Kosovo. Sovereignty, even today has been attractive for the dominant majority of developed countries and for those in developing process, and discussion about those countries that are in transitional process and in process of state-creation as it is Kosovo's case, where interest of its citizens are connected with the desire and their long-term passion for having own state, where it can find its own explaining source and very identical with other neighbor nations.

\section{KOSOVO'S CURRENT ECONOMIC SITUATION}

In fact, Kosovo's economy, actually is in extremely conditions, first of all as consequence of catastrophic damages made by war and the dragging of privatization process, it cannot be revitalized and even less to secure necessary 
phase of prosperity, without any "infusion" of foreign direct, indirect or portfolio investments. It is known fact that due to the demolition of economy during occupation period, Kosovo's industry is reduced by falling in its pre-industrial phase, with heavy consequences such as unemployment growth especially among young people, and also for the existence of extremely poverty population.

Until February 2008, Kosovo didn't gained yet it's sovereignty and was under Interim Protectorate of UN, it's development cannot lay in inflationary investments, but in foreign direct investments and investment loans from international financial institutions or financial capital of foreign banks. As conclusion, in law for foreign investments, as addition of foreign direct investments, investment loans must be included for international financial institutions and financial capital.

When whole this situation is seen in context with low level of economic development, with $40 \%$ of unemployment, GDP of about $2800 \$$, with unfavorable trade balance with other countries, where only 20 percent of import is covered by export and extreme poverty in which Kosovo population is reduced, clearly is seen that there are multidimensional problems that could prevent the solution for economic crises in Kosovo. Gross Domestic Product in Kosovo is about 2800\$ per capita, there isn't any opportunity to increase it from other incomes, respectively to share a part of it in accumulation fund, to secure a well expanded economic development of country in transitional phase. When crises solving opportunities are discussed, the prosperity process will start in Kosovo in many aspects, by taking into consideration endogenous and exogenous factors, which determine the start of prosperity and the given solution for economic crisis.

Emerging from the crisis and so waited start of prosperity, the current situation cannot be supported beyond in declarative desires and with no base hypothesis, but in first row, in contexts with factual opportunities, in which current level of economic development of Kosovo can offer. Deep conviction that exists among citizens in Kosovo along with standards priority implementation, institutional independence must be forced, first of all as necessity that will help to achieve pretended economic development and start of prosperity during actual transitional phase. International economic cooperation of a country, is result of economic development level and economic structure development of respective country, region respectively. Therefore, Kosovo's international economic cooperation depends on two main factors, who designates general frames, dynamic and main directions of this cooperation. Trade strategy of Kosovo must address also the connection with neighbor economies. Fee and non-fee obstacles from some neighbor jurisdictions have impact in negative way in Kosovo's export, transit problems are added to the above mentioned issues, by increasing cost of imports and by reducing export competition. 


\section{AIM OF BEING PART OF EUROPEAN UNION}

EU membership is seen as essential process for Kosovo's in further domestic and international development. EU membership is believed to bring economic, political and security benefits, which are essential for Kosovo's challenges. Kosovo has clear domestic challenges to deal before accession process might start, but EU has its own interests; the fight against corruption is with high importance along with the rule of law enforcement. It is in the EU's own interest to make Kosovo a success story and to secure a stable democratic state due to its geographical location. Due to Kosovo's problem with corruption and organized crime, a worstcase scenario for the EU would be a free trade zone for organized crime, traffickers and terrorists, and a return of conflict.

The EU's main focus has been in the past and it is actually to encourage Kosovo and Serbia to get focused in their European future; it has not sought to change the domestic situation inside Kosovo. Since 2012, there has been an intensification of the relationships between the EU and Kosovo, and there have been important developments of a practical nature, which increase Kosovo's duties fulfillment toward the Union. The Commission and The High Representative of the Union for Foreign Affairs and Security Policy, in recent time reported that Kosovo had met all short- term priorities set out in the feasibility study. The SAA is generally recognized as the first formal step for Balkan states toward EU membership. The SAA is an important milestone in Kosovo's European integration process. While this is a step forward for Kosovo, there are still great domestic and external challenges for accession into the EU. Besides the obvious ones of the Copenhagen criteria, and the relationship to Serbia, there are states within the Union, which do not recognize Kosovo's independence. These are obstacles that Kosovo will need to deal with them in the near future before it can start accession process into the Union.

\section{STABILIZATION AND ASSOCIATION AGREEMENT}

In 2012, the European Commission declared Kosovo "largely ready" to start the SAA negotiations in the form of an EU- agreement, after taking some measures in the field, regarding the implementation of rule of law, public administration, protection of minorities and trade. Kosovo was proclaimed ready to open the negotiations and after signing of the first agreement, the European Commission concluded that Kosovo has addressed the aforementioned priorities. This can confirm that the external criteria's are more important than the internal ones. At least the short-term priorities were not sufficient on their own, signaling that the external criteria are more important than the reform and implementation of the internal criteria ${ }^{6}$. The "Commission considered that Kosovo has made serious

\footnotetext{
${ }^{6}$ Sorheim, I, (2014), Kosovo's present challenges, Trondheim,
} 
engagements and constructively in taking steps toward a visible and sustainable improvement of relations with neighbors". As it is clearly shown, Kosovo has large domestic challenges which needs political commitment and a willingness to proceed with the implementation of policies. Obstacles that Kosovo is facing needs to be both overcome for an EU future and to secure a liberal democracy. It is essential for Kosovo's domestic challenges and for EU membership that recommendations are implemented and enforced. As it is indicated, the implementation has not been the problem, but the challenge lies in actual change and enforcement of the laws in place. EU legislation and international standards should be implemented. Northern Kosovo is one of the most delicate problems, which still needs work and progress. Kosovo is obliged to protect minorities, and to promote a multi- ethnic society.

Figure 4. Conclusion of Stabilization and Association Agreement with Western Balkan countries

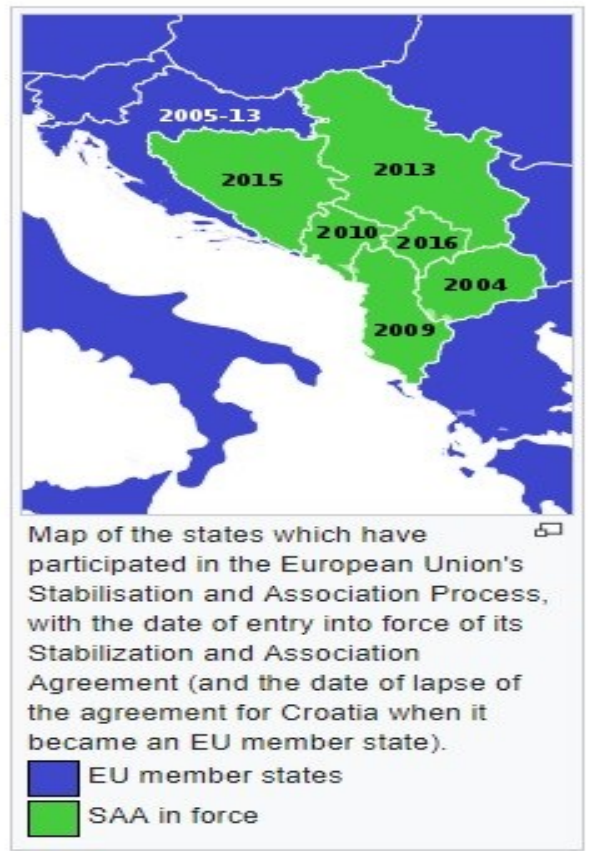

Source: European Commission

Kosovo will need to establish a free trade area where the four main Union policies are guaranteed, including free movement of goods, services and capital. Kosovo will further need to align its national legislation with EU rules, and cooperate more with the EU in certain areas; such as education, social affairs, culture and environment. While these are clearly set out as areas of cooperation, there is uncertainty regarding the EU's role in the implementation of the first agreement in Kosovo. 


\section{COPENHAGEN CRITERIA}

Political criteria conclude that Kosovo needs to achieve stability of institutions guaranteeing democracy, the rule of law, human rights, and the respect for the protection of minorities. The economic criteria related to the existence of a functioning market economy, and the capacity to cope with competitive pressure and market forces within the Union. Potential members need to implement EU legislation. There is also an additional criteria's for the Western Balkans, coming from the 1999 Stability Pact for South Eastern Europe and the Stabilization and Association Process, with a condition of regional cooperation and good neighborhood relations.

Normalization of relations between Kosovo and its neighbors is an EU requirement. The EU stated that this isn't new criteria for membership, good neighborhood relations have always been a demand for potential members. While the SAA negotiations began after the signing of the First Agreement, there are needs that can push forward further development of the relationship between Kosovo and its neighbors before accession process can begin. Kosovo still needs to fulfil key requirements, and deal with the challenges presented before. In spite of the accession process that has started, Kosovo has large challenges in front to overcome before it can achieve membership in the Union.

There has been a critical shift of preconditions that need to be fulfilled for EU integration. Especially the concern discussed above, the external criteria will become more important than the internal criteria. While they are both criteria's for EU membership, it seems more likely that the EU will focus mostly on the external criteria in the case of Kosovo. It even seems like the EU is going to demand more than good neighborliness and good regional relations.

Ministers Council and the European Council must act unanimously when taking enlargement decisions. One state could stop the accession process, if it believes that it might not be in its interest. The enlargement decisions are largely based on the Commission's reports and with recommendations. However, with the nonrecognizers, Kosovo faces an extra challenge to its accession process. Potential members will only be permitted for membership when it is judged that their accession will have beneficial consequences for the whole EU.

\section{EVALUATION OF FULFILLED CRITERIA}

The European Commission issues a Yearly Progress Report. The purpose behind this is to develop and strengthen communication about the challenges that Kosovo is facing, and to recommend measures that the government should take in the view of accession to the EU. The government of Kosovo is committed for EU membership, and has adopted laws to make accession into the EU a possibility. 
The problem for Kosovo isn't the adoption of laws, but their implementation and enforcement.

For EU membership, Kosovo will need to fulfil the Copenhagen political criteria, i.e., stability of institutions which guarantees democracy, the rule of law, human rights, respect and protection of minorities. It also monitors regional cooperation and good neighborhood relations. Already in 2009, democracy, respect for the rule of law, corruption, and the protection of minorities were set as priorities for Kosovo's progress toward the EU. Those are still the main challenges Kosovo faces today in terms of the political criteria, and its aspirations toward establishing a liberal democracy. As these are direct criteria's and requirements for $\mathrm{EU}$ accession, Kosovo will need to demonstrate actual willingness and improvement in these areas before it can make further steps toward the Union. Kosovo seems to have experienced a democratic setback in its efforts to build strong and independent institutions of democratic governance. There are several issues of serious concern, which could harm Kosovo's aspiration toward EU membership.

In terms of administrative independence, Kosovo has made little progress since the EU reports began, especially in terms of financial and administrative independence. Corruption is hindering Kosovo's progress in both democratization and economic development. The lack of transparency and accountability is a high concern issue, according to the 2017 Progress Report. Corruption and political interference are hindering professionalism, and Kosovo will need to demonstrate change in these areas. Overall, Kosovo must demonstrate actual change, and implementation of legislations in all areas. Kosovo has the lowest level of democratic processes and in national democratic governance of all regional countries. Freedom House ranks Kosovo as a semi- consolidated Authoritarian regime.

Both the Progress Report and Freedom House's findings, illustrate the challenges that Kosovo is facing in regards with the rule of law, and especially in terms of corruption. The situation is of serious concern, according to the Progress Report. For Kosovo admission to the EU, effective prevention of corruption in all levels of society needs to be have high priority level. When Kosovo signed the SAA, the EU held that it had met the short- time criteria. When it comes to accession into the Union, Kosovo will need to demonstrate concrete action in enforcing the Copenhagen criteria. The only concrete action that Kosovo has taken is the implementation of a legal framework in accordance with EU's standards and it has not demonstrated any actual enforcement or actions to improve the domestic situation. Kosovo will not be able to join the EU before necessary changes are carried out, especially in fighting corruption.

While this can possibly change with the First Agreement according to the 2017 Report. According to the Progress Report from 2017, the First agreement "represents a fundamental change in relations between the two sides". In the 2010, 
in Yearly Progress Report, key priority was that Kosovo needs to offer delivery public services in the whole of Kosovo.

To join the EU, Kosovo will need to have full commitment for human rights. Kosovo will need to continue to cooperate according to the ad hoc agreements, and report regularly to the UN treaty bodies and the Council of Europe on human rights. During the period that the EU Reports have been issued, there has been limited progress with regards to the promotion and enforcement of human rights. The main challenges fall in the protection of civil and political rights. The Yearly Progress Report of 2017, holds that Kosovo's key challenge in relations to human rights is to "improve implementation of the existing legal framework and enforcement of decisions remedying human rights infringements.

Kosovo's challenges in the protection of human rights fall in the freedom of expression, protection of minorities, freedom of assembly, freedom of thought, conscience and religion, women's rights and gender equality, anti- discrimination.

While much of Kosovo's legislation on human rights is in line with international standards, Kosovo's challenge is the implementation and improvement of the actual situation. Kosovo remains reliant upon support from the international community in the area of protection of minorities. The difficulties that Kosovo is facing in regards to the protection of human rights, is great challenge for the development of a liberal democracy, but also is a direct hindrance for $\mathrm{EU}$ accession. To secure success, recommendations from international bodies should be implemented.

The other side of the Copenhagen Criteria is related to the economic situation. Membership in the Union requires existence of a functioning market economy and the capacity to cope with competitive pressure and market forces within the Union. Corruption and lack of clear political willingness, are seen as obstacles in the area of economic development. The high level of corruption and unemployment in this area are directly hindering membership. While foreign direct investments (FDI) are held to be the solution by the Kosovo's government, this will not happen with the high level of corruption. In 2016, FDI even declined to the lowest level since 2005, according the Yearly Progress Report from 2017. The weak level of rule of law and underdeveloped policy framework have continued to hamper the economy.

For EU membership, Kosovo will need to demonstrate full compliance with EU standards. To estimate a time frame for this process is impossible, due to the many challenges and incalculable variables in play. Kosovo clearly does not satisfy the Copenhagen criteria. Previous Progress Report describes Kosovo as far away from European standards. When Kosovo has signed the SAA, despite not having deal with all necessary challenges, it has sent signal that it has understood that it will not receive membership until actual changes have taken place. In order to fulfil the 
Copenhagen criteria, Kosovo needs to make more efforts, and there is rapid need for radical change in the whole society, to roll back corruption, democracy strengthening and the rule of law.

Kosovo has a complicated relationship with the EU, as the country is committed for accession, but in the same time, lack of the political will have to act upon recommendations. As the indicators from the Freedom House shows that Kosovo has large challenges in its aspiration for EU accession. Due to earlier mistakes that were committed by the EU in previously member's admission, Kosovo needs to demonstrate full compliance with EU standards. Bulgaria and Romania waited 12 years for membership after their application, but this still is perceived as too rapid. Rapid accession to the EU, have experienced difficulty in intervening in a country's internal politics once it has become a member. This means that Kosovo needs to demonstrate political acceptance and willingness along with enforcement of the recommendation to show progress in its aspiration to gain EU membership.

\section{DIFFICULTIES FOR KOSOVO IN INTEGRATION PROCESS}

With the difficulties that Kosovo is already facing in its accession process, there are other factors which could delay it even more. Due to Kosovo's domestic challenges and its small size, with few available resources, the benefits for the EU are minimal. Kosovo's membership to the EU is unlikely without domestic improvement, due to the costs in terms of political tension, weak democracy and corruption. There are few benefits for the EU to accept Kosovo as a member to the Union. For membership Kosovo would need to maximize the perceived benefits, and minimize the cost, i.e., fight corruption.

In terms of getting accepted as a member of the Union, the clearest external obstacle is the resistance of states within the EU, which have not recognized Kosovo's independence: Spain, Greece, Slovakia, Romania and Cyprus. The five non- recognizers within the EU have prevented further advancement of Kosovo on the international scene. The position of the non-recognizers within the EU has weakened Kosovo's claim, and led to the lack of recognition from the EU as a legal entity. But the biggest obstacle is their ability to hinder Kosovo from joining the EU, if it by a miracle did fulfil the Copenhagen criteria. In order to be accepted into the EU, Kosovo needs full recognition and a consensus within the Union. This could then evolve into a situation where these five could block Kosovo's membership.

The prospect for success is also limited. The normalization of relations is essential for EU membership, as the Union clearly does not want to import internal security problems. Cyprus accessed the Union at the same time when the authority of the government wasn't extended to the Turkish territory, and the EU has made it clear in which such the same situation, will not be permitted for Kosovo. 
Without the singing of the First agreement, Kosovo doubtfully would have received the SAA. It is further held that such a new criterion should not have been added, and Kosovo's way into the EU should be negotiated separately from that of Serbia. To prevent further problems in for Kosovo's road toward EU membership in the external criteria, the term of normalization should be defined, with a official time frame for this announced.

\section{a. Relationship's with European Union}

Despite the lack of diplomatic recognition, Kosovo has started the SAA negotiations, it remains unclear if this agreement will be ratified by all of the Union members once it is finished. Non- recognition of Kosovo's independence could prolong the accession process even more. The EU has for now set aside Kosovo's domestic challenges, and chosen to focus on the external one, and the normalization of relations with Serbia. But it is certain that the Copenhagen criteria will serve as the basis for Kosovo's accession into the Union. Kosovo is the only state in the region, where the path toward EU membership is not based on a contractual agreement.

EU has not fulfilled its promise to Kosovo, as it was led to believe that it would receive visa liberation for the technical dialogue with Serbia. Originally the requirements for the SAA and visa liberation overlapped with each other. This is an indicator of the challenge it's facing in its aspiration to obtain membership and the difficulties, which lie ahead. While the domestic challenges were put aside for the SAA, it has not been put aside for the visa liberation. This situation also shows the incomplete EU policy on Kosovo. Taking into consideration the challenges of corruption and lack of economic development, and the absence of a clear EU position and lack of recognition, this could be an optimistic view.

\section{CONCLUSION}

In order to become a fully recognized member of the international community, and to enter the EU, the prerequisite for Kosovo is to develop a liberal democracy. This is clearly set as a criterion for potential EU candidates, and it is in Kosovo's own best interest to function as a liberal democracy if it is going to be accepted into the international community. Kosovo has today no prospects of being admitted into the UN. Today there are 115 states that recognize Kosovo's independence. As this thesis has shown, Kosovo's disputed statehood is known above all as a political problem, and not a legal one. Kosovo is in the unusual position of having been neither effectively accepted, nor rejected, by the international community at large.

Kosovo's domestic challenges are a direct obstacle for EU membership. The implementation of EU legislation has started. Some recommendations have been followed up upon, but the EU demands actual enforcement and a willingness to 
change. The main challenges lie in the same areas as in the establishment of a liberal democracy, the rule of law, economic development, and stable political institutions. An additional challenge to Kosovo's aspiration to gain EU membership is the lack of legal recognition from some of the members of the Union itself. However, it is clear that accession into the Union will not depend solely upon the EU, but for membership in the EU, Kosovo will need to intensify its campaign against corruption and show progress on all the required criteria. It will take much time and effort for Kosovo to improve its record on the domestic aspects of EU requirement, and not least, willingness for the politicians. So far, the requirements are not satisfied. To have any chance of achieving accession into the EU, above all, domestic change is needed. Kosovo is facing challenges and becoming a state based on the principles of democracy, the rule of law and human rights.

Kosovo is not a country based on democratic values, nor is it a system of parliamentary democracy despite the reassurance in the constitution. Corruption and the homogeneous political system are undermining the democratic system and the core foundation of a liberal democratic state. The political system needs to have a liberal character, which is defined by the rule of law, toleration, a commitment to equality, and the protection of basic liberties of speech, assembly, religion, and property.

Today, Kosovo is described as a corrupt polysepalous oligarchy. Democracy entails other crucial elements, such as multi-party elections - this has been realized only superficially in Kosovo where there is no real choice in politics. The lack of separation of powers is hindering the development of a stable democratic state.

Corruption is undermining all functions of the state, and is a threat to the stability and sustainability of Kosovar institutions. Economic development will not take place until corruption is dealt with; this entails enforcement of the legal framework in place. To have a functioning democratic state, a certain degree of economic prosperity is necessary. Unemployment, poverty, and the trade deficit need to be prioritized if Kosovo is to move forward. According to the World Bank, corruption and bribery remain a key factor deterring companies from investing in Kosovo. Corruption is an obstacle to attracting investment, hence is a obstacle for economic development. The fight against corruption and organized crime is one of the key criteria for Kosovo's further European integration.

Kosovo's key challenges are to implement and enforce the existing legal framework, especially to enforce decisions remedying human rights infringements. In order to ensure the development of a liberal democracy the focus should be on integration rather than segregation of the Kosovar Albanian and Kosovar Serb population. All of these are essential factors in the development of a democratic life. 
Kosovo faces large challenges in the development of a liberal democratic state. It is of outmost importance that it accomplishes change and improvements economically and institutionally. Programmatic pluralization in politics needs to be pursued, along with the establishment of the rule of law. It should secure a liberal character by guaranteeing individual rights, equality and the protection of human rights, all of which are essential for a liberal democracy, Kosovo needs to develop a political system, which is defined not simply by free and fair elections, but also the rule of law, toleration, a commitment to equality, and the protection of basic liberties of speech, assembly, religion, and property. To tackle the domestic challenges is essential not only to liberal democracy, but also for the political and social stability which Kosovo needs to move forwards - both into the international community, and in its aspiration on joining the EU.

\section{REFERENCES}

1. Ahtisaari, M, Ischinger, W, and Rohan, A, "Kosovo is Europe's responsibility"

Project Syndicate, February 11, 2009, at http://www.projectsyndicate.org/commentary/ahtisaari3/English (accessed on 6 September 2013)

2. Cocozzelli, Fred, "Between Democratisation and Democratic Consolidation: The Long Path to Democracy in Kosovo" in Perspectives on European Politics and Society, Vol.14, No.1 (February 2013),

3. Diamond,Larry, Seymour Martin Lipset, and Juan Linz, "Developing and sustaining democratic government in the third world" in World Affairs Vol.150, No. 1 (Summer 1987),

4. Feltes, Tilmann, "Youth and Democracy: The Promotion of Youth Participation by the International Community in Kosovo" in Security and Human Rights, Issue 24 (Number 2 2013),

5. Holmes, Leslie, "Crime, Corruption and Politics: Transnational Factors" in Jan Zielonka and Alex Pravda (eds.), Democratic Consolidation in Eastern Europe: Volume 2, International and Transnational Factors (Oxford: Oxford University Press,2001),

6. Judah, Tim, Kosovo: What everyone needs to know, (New York: Oxford University Press, 2008),

7. Ker-Lindsay, James, "Principles and the Partition of Kosovo" in Peace Review: A Journal of Social Justice, Vol. 23, No. 2 (June 2011),

8. Malazogu, Leon, Filip Ejdus, Milan Nic, and Tomasz Zornaczuk, "Integration or Isolation? Northern Kosovo in 2014 Electoral Libo" in Democracy for Development / Central European Policy Instititute (14 February 2014) at, http://d4d-ks.org/assets/CEPI-Integration-orIsolation.pdf,

9. Mehmeti, Jeton, and Agron Demi, "Institutions and political structures- how far is Kosovoa?" in Olaf Leiße, Martin Roth and Christian Gesellmann (eds.) 
Die Republikk Kosovo- Der jüngste Staat Europas. Eine politische Bestandsaufnahme seit der Unabhängigkeitserklärung (Baden-Baden: Nomos 2013),

10. Ramet, Sabrina P., "Civic and uncivic values in Kosovo: an introduction" in Sabrina P. Ramet, Albert Simkus, and Ola Listhaug (eds.), Civic and uncivic values in Kosovo: Value transformation, education, and media (Budapest and New York: Central European University Press, forthcoming),

11. Ryngaert, Cedric, and Sven Sobrie, "Recognition of States: International Law or Realpolitik? The Practice of Recognition in the Wake of Kosovo, South Ossetia, and Abkhazia" in Leiden Journal of International Law Vol. 24, No.2,

12. Suny, Ronald Grigor, and Vicken Cheterian, "Making states and breaking states: Kosovo and the Caucasus in 2008: Introduction" in Nationalities Papers: The Journal of Nationalism and Ethnicity, Vol.40, No.5,

13. Ulram, Peter A., and Fritz Plasser, "Political Culture in East- Central and Eastern Europe: Empirical Findings 1990-2001" in Detlef Pollack, Jörg Jacobs, Olaf Müller and Gert Pickel (eds.), Political Culture in PostCommunist Europe,

14. Wilson, Gary, "Self- determination, recognition and the problem of Kosovo" in Netherlands International Law Review Vol. 56, No. 3,

15. Woodward, Susan L, Is democracy possible in the Balkans? On preconditions and conditions in Bosnia, Kosovo and Serbia (Seattle, WA: National Council for Eurasian and East European Research, 2007),

16. Zakaria, Fareed, "The rise of illiberal democracy" in Foreign Affairs, Vol. 76, No. 6 (November- December 1997), 